\title{
Meningoencephalitis in central-southern sicily: most frequently observed viruses
}

\begin{abstract}
4811 tests for neurotropic virus detection were carried out on patients in centralsouthern Sicily. The most often isolated virus both in male and female genders was HSV1, followed by VZV for men and HHV6 for women.
\end{abstract}

Keywords: encephalitis, HSV1, HSV2, HCMV, EBV, VZV, HHV 6, enterovirus
Volume 5 Issue 3 - 2018

\author{
Salvatrice Mancuso, Rosalba Collodoro, \\ Giuseppina Di Forti, Santina Samantha \\ Mastrosimone, Alessandro Polizzi, Liborio \\ Bellomo \\ UOVirologia ASP2 Caltanissetta, Italy
}

Correspondence: Liborio Bellomo, UO Virologia ASP2 Caltanissetta,Via L. Russo N 6-Caltanissetta, Italy, Tel 0934 559555, Fax 0934-55955I,Email liborioballomo@virgilio.it

Received: September II, 2017 | Published: November I5, 2018
Abbreviations: HSV1, herpes simplex virus 1; HSV2, herpes simplex virus 2; HCMV, human cytomegalovirus; EBV, epstein barr virus; VZV, varicella zoster virus; HHV 6, herpes simplex virus 6

\section{Introduction}

Introduction should provide background, comprehensive insight on the purpose of the study and its significance. Viral etiologic agents of Encephalitis are Herpesviridae, Picornaviridae, Paramixoviridae, Retroviridae, etc. They may have their own seasonality. ${ }^{1-4}$ In the studies realized from 2010 to 2015, 4811 cerebrospinalfluids(CSF) were tested for Cytomegalovirus (CMV-DNA), Herpes virus 1 (HSV1-DNA), Herpes Virus 2 (HSV1-DNA), (VZV-DNA) and Enterovirus (Entero-DNA) with the Real-Time PCR method (Real Time Complete Elitech Kit ). ${ }^{5}$ The serum of the same patients was tested for IgM antibodies (Vidas-M Biomerieux Kit). Therefore, it is possible to determine if there is a correlation between infections and environmental temperatures and find out how to contain the phenomenon and the most frequent viruses.

\section{Conclusion}

Among the 4811 samples tested, 4750 (98.73\%) were negative and $61(1.27 \%)$ were positive: 181 came from HIV positive patients, but only one of them was reactive (Table 1). The low rate of positivity found in HIV-positive patients requires further insights. Among the 4811 tests performed, only in two cases the IgM antibodies have been detected (data not shown). The correlation between the temperature variation in the different seasons and the increase in the cases of encephalitis was examined yearly: statistical analysis indicates that this ratio is not significant: $\mathrm{p}<0.001$ (data not shown). Most positive patients were men (51\%); the most commonly isolated virus in the two genera is HSV 1, followed by VZV for men and HHV6 for women and followed by EBV for men and VZV for women. From history and laboratory data in patients with IgM positivity, it is clear that there has not been any acute infection but rather a reactivation. This issue shows that encephalitis is present in the territory under examination, therefore, the greatest attention should be paid to the monitoring of the conditions of patients at risk: HIV positive, immunodeficient, transplanted, etc. This data is corroborated by the confirmation that the antibody positivity, according to the data in our possession, is often due to the reactivation of the infection rather than to an acute phase of the disease.

Table I Tests performed on patients from 2010 to 2015

\begin{tabular}{lllllllll}
\hline Virus & Men & \multicolumn{3}{c}{ Women } & \multicolumn{3}{l}{ HIV positive } & Total \\
\hline & Tot & Pos & Tot & Pos & Tot & Pos & Tot & Pos \\
\hline CMV & 322 & 3 & 341 & 0 & 23 & 0 & 686 & 3 \\
EBV & 323 & 5 & 342 & 2 & 22 & 1 & 687 & 8 \\
HSV-1 & 324 & 11 & 342 & 11 & 45 & 0 & 711 & 22 \\
HSV-2 & 319 & 4 & 340 & 3 & 23 & 0 & 682 & 7 \\
HHV-6 & 321 & 1 & 340 & 7 & 23 & 0 & 684 & 8 \\
VZV & 322 & 6 & 337 & 4 & 23 & 0 & 682 & 10 \\
ENTERO & 319 & 1 & 337 & 2 & 23 & 0 & 679 & 3 \\
\hline
\end{tabular}

Abbreviations: HSVI, herpes simplex virus I; HSV2, herpes simplex virus 2; HCMV, human cytomegalovirus; EBV, epstein barr virus; $V Z V$, varicella zoster virus; HHV 6, herpes simplex virus 6

\section{Acknowledgements}

Authors would thank Miss Antonella Lattuca, English teacher, for the valuable and effective collaboration and Mrs Annalisa Agnone, Biologist, for the kind contribution.

\section{Conflict of interest}

I state that none of the Authors have any financial or other conflict of interest.

\section{References}

1. Ik L Tan, Justin C McArthur, Arun Venkateasen, et al. Atypcal manifestation and poor outcome of herpes simplex encephalitis in the immunocompromissed. Neurolgy. 2012;79(21):2125-2132.

2. Uluhan Sili, Abdurrahman Kaya, Ali Mert, et al. Herpes simplex viruos encephalitis: clinical manifestations, diagnosis and outcome in 106 adult patients. Journal of Chinical Virology. 2014;60(2):112-118.

3. Anibal G Armien, Shuxian Hu, Morgan R, et al. Chronic Cortical and Suncortical Pathology with Associated Neurological Deficits ensuing 
Experimental Herpes Encephalitis. Brain Pathol. 2010;20(4):738-750.

4. Sara Tremolada, Serena Delbue, Pasquale Ferrante. Viral Infections of Fetus and Newborn Infant. Pediatr Med Chir. 2008;30(4):177-191.
5. Martin Ludlow, Jeroen Kortekaas, Cristiane Herden, et al. Neurotropic virus infections as the cause of immediate and delayed neuropathology. Acta Neurophatologica. 2016;131(2):159-184. 